\title{
Foreign Direct Investments: Structure and Dynamics in Russia
}

\author{
Gulnaz M. Galeeva ${ }^{1}$, Elena P. Fazlieva ${ }^{2}$, Adel A. Daryakin ${ }^{3}$, Elena N. Zagladina ${ }^{4}$ \\ ${ }^{1,2,3}$ Kazan Federal University, Institute of Management, Economics and Finance , ${ }^{4}$ Kazan Federal University, Institute \\ of International Relations, History and Oriental Studies, \\ Email: 49enzagladina52@gmail.com Contact: 89033050481
}

\section{Received: 21st October 2017 Accepted: 16th November 2017, Published: 31st December 2017}

\begin{abstract}
In this paper, we consider the structural dynamics of foreign direct investment that entered the Russian economy during the period of 2009-2015. In this regard, the main forms, methods and instruments of foreign direct investment were presented and the main areas of investment were highlighted. The study consisted of several stages and was based on the data published on the official websites of YUNKTAD, IMF, CBR. Leading countries on foreign direct investment attraction, the strategies and the methods for investment attraction were studied, the major sources of investment and the countries of origin were identified. In 2014-2015 20 countries were revealed, which were the leading ones in terms of foreign direct investment attraction, including the United States, Hong Kong and China. High investment values were observed among the countries that are leaders in the number of mergers and acquisitions (US). The priority areas of investment are engineering, information and medical technologies, biotechnologies. A special feature of foreign direct investment structure accumulated in Russian Federation by investor countries is the significant role of offshore investments. The share of Russian Federation in the global inflow of foreign direct investment decreased to $0.6 \%$ in 2015 against $3.7 \%$ in 2013 .
\end{abstract}

Keywords: Direct Foreign Investment, Economy, Mergers and Acquisitions, Investment Rating

\section{Introduction}

Foreign investments are the basis for economic development, the competitiveness of domestic production increase, the acceleration of economic and technological progress and the country export potential expansion. The state regulation of investments in the form of direct capital is carried out on two vectors: the control of foreign investment entry (the assessment of scale, distribution by industry and territory, forms) and the control of capital imports.

It is worth to highlight a universal set of incentive measures that is used in world practice to attract foreign direct capital: tax measures (the granting of tax privileges or "tax holidays" to an investor, his exemption from customs duties or fees); financial measures (an investor is provided with the subsidies from the government, grants, concessional credits and loans); the creation of a favorable investment climate, the creation of special economic zones, legislative base and the infrastructure necessary for investment activity.
These incentive measures are combined and used in many countries to attract foreign capital. In recent decades, the following features of FIA have developed in the countries with different levels of socialeconomic development. The countries with a high level of social-economic development focus on financial measures to stimulate investment. The developing countries prefer tax measures due to the fact that they lack the necessary financial resources to enhance investment. The second feature is the emerging stable trend towards the widespread use of non-financial incentives, for example, the creation of special economic zones with FIA attraction, the simplification of administrative procedures for opening and doing business to foreign investors.

The main forms of foreign direct investment are considered to be the creation of joint and subsidiaries and companies, the opening of its own branches and the M\&A transaction. The importance of foreign investment in the economy of modern states increases, therefore they require regulation and control at the international and national level. Thus, it is necessary to use a systematic approach to understand the state regulation of foreign direct investment, taking into account the common interests of a host state and a foreign direct investor. The need for such state regulation is associated with the possible risks and negative consequences of uncontrolled inflow of FIA into the economy of the recipient country, as well as with the multidirectional interests of a foreign investor and the capital recipient state.

\section{Materials and Methods}

The material for the work was the data of the Yuktad, the IMF, the Central Bank of Russian Federation, as well as the data on transactions concerning the transnational mergers and acquisitions. The latter are currently the main factor that determines the level and direction of foreign direct investment movement. Connecting and "absorbing" each other, transnational corporations concentrate economic power in their hands and make a significant impact on the economic policies of the countries and on the development of individual markets. The total amount of transactions on mergers and acquisitions increased by $30.4 \%$, or up to 4.276 trillion according to the data of 2015 which exceeded the previous pre-crisis maximum by $16.5 \%$ in 2007 (3.67 trillion US dollars) (see Figure 1). USA became the leader among the countries in terms of the aggregate value of mergers and acquisitions: this country accounted for about $50 \%$ of the total value of 
transactions at the global market, which is conditioned by traditionally high business activity of US companies and a high dollar rate. As for Russia, it takes 25th place in the rating on this indicator.

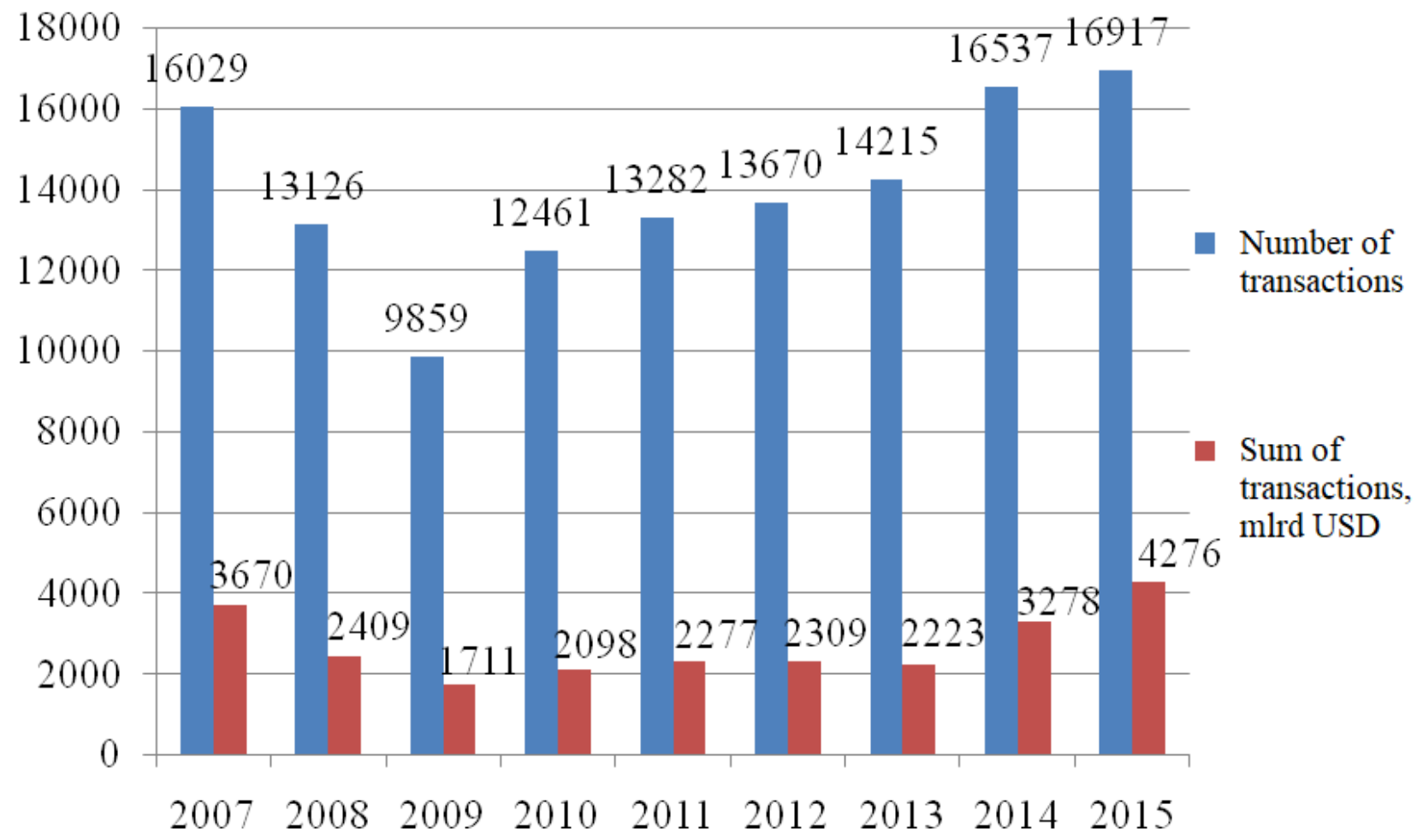

Fig. 1. M\&A World Market

In modern world, the use of different countries as the strategy of mergers and acquisition mechanisms by companies brings them important competitive advantages. The successful development and the efficiency of any company activity depends on its place at the market, and the effectiveness of the company development strategy is determined by time during which it will be able to capture a certain niche in the markets of many countries, which will allow it to dictate its interests and conditions.
Let's consider top 10 countries - the largest recipients of FIA in 2015 (see Table 1). The United States became the leader in FIA during 2015, followed by Hong Kong, China, Ireland and the Netherlands. It is of interest to study the experience of a number of countries (China, Singapore, Brazil, India, South Korea, Switzerland) with a developed and developing economy that have achieved significant results in foreign capital attraction. So, let's consider their economic, political and social-cultural characteristics and selected strategies for FIA inflow increase into the national economy.

Table 1. 20 Countries - The Largest Recipients of Foreign Direct Investment in 2014-2015

\begin{tabular}{|c|c|c|c|c|c|c|c|c|c|}
\hline \multirow[b]{2}{*}{ Country } & \multicolumn{2}{|c|}{2014} & \multicolumn{2}{|c|}{2015} & \multirow[b]{2}{*}{ Country } & \multicolumn{2}{|c|}{2014} & \multicolumn{2}{|c|}{2015} \\
\hline & place & $\begin{array}{c}\text { Volum } \\
\text { e, } \\
\text { billons } \\
\text { of USA } \\
\text { doll. }\end{array}$ & place & $\begin{array}{c}\text { Volum } \\
\text { e, } \\
\text { billons } \\
\text { of USA } \\
\text { doll. }\end{array}$ & & place & $\begin{array}{c}\text { Volum } \\
\text { e, } \\
\text { billons } \\
\text { of USA } \\
\text { doll. }\end{array}$ & place & $\begin{array}{l}\text { Volum } \\
\text { e, } \\
\text { billons } \\
\text { of USA } \\
\text { doll. }\end{array}$ \\
\hline Hong Kong & 3 & 107 & 1 & 380 & France & 20 & 15 & 10 & 43 \\
\hline China & 2 & 114 & 2 & 175 & $\begin{array}{l}\text { United } \\
\text { Kingdom }\end{array}$ & 7 & 52 & 11 & 40 \\
\hline Ireland & 1 & 129 & 3 & 136 & Germany & 98 & 1 & 12 & 32 \\
\hline Netherlands & 11 & 31 & 4 & 101 & Belgium & 189 & -9 & 13 & 31 \\
\hline Switzerland & 8 & 52 & 5 & 73 & Mexico & 13 & 26 & 14 & 30 \\
\hline Singapore & 38 & 7 & 6 & 69 & Luxembourg & 23 & 12 & 15 & 25 \\
\hline Brazil & 5 & 68 & 7 & 65 & Australia & 9 & 40 & 16 & 22 \\
\hline Canada & 4 & 73 & 7 & 65 & Italy & 14 & 23 & 17 & 20 \\
\hline India & 6 & 59 & 8 & 49 & Chile & 17 & 21 & 18 & 20 \\
\hline Hong Kong & 10 & 35 & 9 & 44 & Turkey & 22 & 12 & 19 & 17 \\
\hline
\end{tabular}


The People's Republic of China is a typical example of the country that has succeeded in direct foreign capital attraction. The success of China in foreign investment attraction is considered to be one of the main factors that ensure the rapid growth of the Chinese economy during the last two decades. In 2014, on the volume of attracted FI, China outstripped the US for the first time, thus becoming the world's largest importer of foreign direct investment. Following the results of 2015, China position went down 2 lines down in the list of 20 leading countries for FI attraction, and the country took the third place with the result of 136 billion dollars. However, in 2016, under the conditions of FI flow significant reduction around the world, and especially in Asia, China has steadily increased the attraction of foreign investment. As compared to the previous year, the growth was $2.3 \%$ and reached 139 billion dollars, which was a new historical maximum for it. Considering the World Investment Report by UNCTAD, it is worth noting a significant rise of FI import rate during 2014-2015 carried out by Switzerland, which, from the 38th rating position in 2014 (7 billion dollars), climbed to the 6th place in 2015 (69 billion dollars). According to Swiss the priority areas for foreign investment attraction at the moment, including Russian ones, are represented by the variety of innovative technologies. These include engineering, information and medical technology, and biotechnology.

Indeed, each country has its own scale of these factors priority and importance, but as the experience of most countries shows, macroeconomic stability, predictability, liberalism and the consistency of laws and regulations, a well-developed infrastructure, the protection of property rights, the granting of tax benefits, preferences and other incentives, skilled labor are the fundamental factors that have the greatest impact on the decision-making concerning foreign direct investment.

\section{Results and Discussion}

During the study period they revealed that the statistics of accumulated direct foreign investments in the context of investing countries (Table 2) is of great importance during the analysis of investment processes in Russia. The first 7 leading countries account for $75.7 \%$ of foreign direct investment accumulated in Russia, and all these countries are used to some extent as offshore zones, namely offshore countries are represented by Cyprus, Luxembourg, Bahamas, Bermuda and British Virgin Islands.

Thus, the main feature of foreign direct investment structure accumulated in Russia by investor countries is the significant role of offshore investments. According to the information provided in Table 2, Cyprus, Luxembourg, the Netherlands, Ireland, the Bahamas, the British Virgin Islands, Bermuda and Germany are the leading investor countries in the economy. By the beginning of 2016, Russia had accumulated 336.3 billion US dollars of foreign direct investment, so the share of these countries in the total amount of accumulated foreign investment is $81 \%$.

Table 2. Foreign Investment in Russian Federation (Equity Participation and Debt Instruments) from some Countries (Balance at the End of the Year)

\begin{tabular}{|l|c|c|c|c|c|c|c|}
\hline \multicolumn{1}{|c|}{ State investing into RF } & 2009 & 2010 & 2011 & 2012 & 2013 & 2014 & 2015 \\
\hline Cyprus & 129,9 & 179 & 128,8 & 150,4 & 193,6 & 110,3 & 94,6 \\
\hline Luxembourg & 14,4 & 19,7 & 20,3 & 30,3 & 42,9 & 39,4 & 41,1 \\
\hline Netherlands & 33,6 & 40 & 59,7 & 59,6 & 64,5 & 53,3 & 40,4 \\
\hline Ireland & 0,2 & 3,8 & 8,9 & 18,9 & 29,1 & 26,4 & 31,7 \\
\hline Bahamas & 18,7 & 24,6 & 27,1 & 29,3 & 32 & 21 & 21,6 \\
\hline Brit. Virgin Islands & 36,6 & 51 & 56,4 & 49,0 & 26,3 & 14,7 & 15,3 \\
\hline Bermuda & 27,2 & 49,2 & 34,6 & 31,2 & 29,8 & 15,4 & 14,1 \\
\hline Germany & 15,3 & 23,1 & 18,7 & 21,5 & 19,2 & 13,9 & 13,5 \\
\hline Switzerland & 5,7 & 6,5 & 6,3 & 6,3 & 6,8 & 11,5 & 10 \\
\hline France & 9 & 11,5 & 15,4 & 17 & 14,1 & 9,7 & 9,9 \\
\hline United Kingdom & 6,5 & 7,8 & 6,3 & 7,2 & 23,1 & 7,9 & 6,8 \\
\hline Finland & 3,6 & 6,6 & 5,4 & 5,5 & 4,3 & 2,7 & 6,7 \\
\hline Austria & 7,4 & 7,8 & 8,3 & 10,1 & 12,2 & 8 & 5,5 \\
\hline Sweden & 11,7 & 18,1 & 16,1 & 15,8 & 16,2 & 3,2 & 2,6 \\
\hline USA & 13,9 & 5,4 & 3,4 & 2,9 & 18,6 & 2,8 & 2,4 \\
\hline China & 1,3 & 2 & 1,4 & 2,2 & 4,5 & 2,8 & 1,7 \\
\hline
\end{tabular}

The dynamics of FI volumes accumulated in Russia for individual countries, which are not commonly referred to offshore, was multidirectional one. The volume of accumulated FI from the United States in 2015 declined by 7.75 times, and from Germany it declined only by 1.4 times as compared to 2013 , and the role of the latter even increased.

\section{Conclusions}

At all stages of economic development, the attraction of capital in the form of foreign direct investment is an essential factor in the development of a host country. The need to attract direct foreign investment in the economy of the host country is that reconstruction, diversification and revitalization of the manufacturing 
sector of the recipient country are possible if they are used. The determining role of foreign direct investment in economic growth is approved by the experience of the countries considered earlier, which in recent decades have made a great leap in their economic development (China, Brazil, India, South Korea, etc.).

According to UNCTAD estimates, Russia received \$ 9.8 billion of direct foreign capital in 2015, and this is a 12-year old minimum. Russia share in the global inflow of FI fell to $0.6 \%$ in 2015 against $3.7 \%$ in 2013. The collapse is determined by geopolitical reasons and the fall of oil prices in 2015. Russia dropped out of the top 20 countries - the leaders in terms of foreign direct investment attraction, but at the same time it continues to be the top 20 world investors. At the same time, it is worth noting a positive correlation between the influx of foreign direct investment and the change in the investment rating of Russian Federation, which is published by the international rating agency Standard $\&$ Poors (the dynamics of this rating change as a whole had a positive growth from "B-" in 2000 to "BBB" in 2013 and by 2016 the decline is to "BB +") (see Figure 2).

\section{Change of investment rating S\&P Russia for 2000-2016}

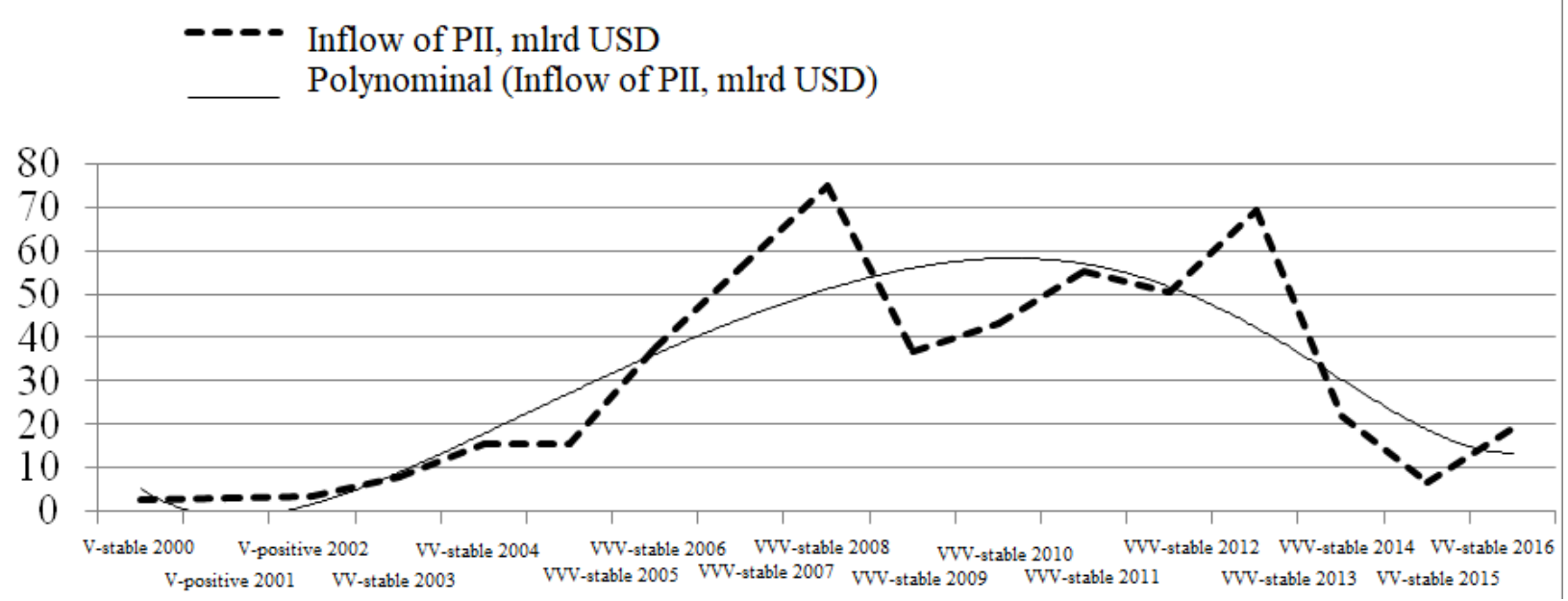

Fig. 2. Dynamics of FI inflow into the Russian Economy during 2000-2016 taking into account the Change in the Investment Rating of S\&P Russia

As of March 2017, Standard \& Poor's Ratings Agency ranked Russian long-term and short-term foreign currency debt rating at non-investment (speculative) level to "BB+ positive" from "BB+ stable". The international rating agency Fitch Ratings confirmed the rating of Russian Federation at the level of "BBB-" with a "stable" forecast in 2017. In the same year the international rating agency Moody's improved its forecast on Russia rating from negative to stable, assigning a speculative level of "Ba1" to Russia. Thus, among three influential rating agencies, only Fitch Ratings still maintains an investment grade rating for Russia. RF ratings from international agencies Standard \& Poor's and Moody's are currently set at the level below the investment one.

\section{Summary}

After the situation analysis that has developed in the sphere of FIA in Russian economy during recent years, a number of basic conclusions can be drawn regarding the nature of their impact on the country economy:

In 2015, Russia fell to 12-year minimum, having received only $\$ 9.8$ billion of foreign direct investment according to UNCTAD estimates. The share of Russia in the global inflow FI fell to $0.6 \%$ in 2015 against $3.7 \%$ in 2013. The collapse is conditioned by geopolitical reasons and the fall of oil prices in 2015 .
All these events of recent years illustrate the lack of Russian economy attractiveness for foreign capital.

The share of accumulated FI in Russia gross domestic product remains insignificant, despite the trend of increase from 2014 to 2016, which indicates a low degree of foreign direct investment participation in the process of the country GDP creation.

The contribution of foreign sources in the development of investments into the fixed capital of Russian economy is not great, and this affects the competitiveness of the economy industrial sector negatively, because investments in fixed assets occupy a determining place for the growth and the development of the national economy. On the contrary, at present, Russian investments, which substantially exceed the volume of direct foreign investments in the fixed capital of Russian Federation, make the foundation for Russian economy growth and development.

There are the differences concerning the directions of foreign direct investment flows in the industry and the needs for their development in Russian economy. Foreign direct investment is mainly sent by investors to the industries that produce commodities of a raw nature and which have a high rate of return and the payback period is minimal. The trends of direct foreign 
investment do not stimulate restructuring and deep modernization of the national economy of Russia.

\section{Acknowledgements}

The work is performed according to the Russian Government Program of Competitive Growth of Kazan Federal University.

\section{References}

1. Bagautdinova N.G., Galeeva G.M., Fazlieva E.P., Arzhantseva N.V. (2014) Investment Attractiveness of the Region as the Factor in the Formation of Competitive Advantages. Mediterranean Journal of Social Science,\#28.9-14. Fortescue S.he Russian steel industry, 1990-2009. Source of the Document Eurasian Geography and Economics. 50 (3), 252-274.

2. Muravyev A. Investor protection and the value of shares: Evidence from statutory rules governing variations of shareholders' class rights in an emerging market. Journal of Law, Economics, and Organization. 29 (6), 13441383.

3. Mergers and acquisitions (M\&A): the results of 2015 in Russia and the world [Electronic resource] / Website "Holding KPI". - URL: http://www.kpi.ru/pressroom/analytics/sdelki_ sliyaniya_i_pogloweniya_ma_itogi_2015_g_v _rossii_i_mire/ (reference date 20.02.2017).

4. The market of mergers and acquisitions in Russia in 2015 [Electronic resource] / KPMG website. - URL: https://assets.kpmg.com/content/dam/kpmg/pd f/2016/05/en-ru-ma-survey-report-may2016.pdf (reference date: February 20, 2017).

5. Global investment trends [Electronic resource] / Official site of "UNCTAD".
URL:http://unctad.org/en/PublicationChapters /wir2016ch1_en.pdf\#page=4 (reference date: 4.03.3017).

6. Location Promotion Switzerland [Electronic resource] / The site of the International Information Center "News of Russia" (KremlinRus.ru). - $\quad$ URL: http://www.kremlinrus.ru/article/167/2020/ (reference date 20.02.2017).

7. 1IMF, Coordinated Direct Investment Survey [Electronic resource] / Official website of the IMF. - URL: http://cdis.imf.org (reference date 26.03.2017).

8. The Bank of Russia. Direct investment in Russian Federation by partner countries in 2007-2015 (participation in capital, reinvestment of income and debt instruments) [Electronic resource] / CBR. - The official site of the Central Bank of Russia. - URL: http: www.cbr.ru/statistics/?PrtId=svs (reference date: March 26, 2017).

9. Global foreign direct investment has reached the post-crisis maximum [Electronic resource] / Electronic periodical "Vedomosti". URL:https://www.vedomosti.ru/economics/art icles/2016/06/23/646445-pryamie-inostrannieinvestitsii (reference date: 2.04.2017).

10. Russia - credit rating [Electronic resource] / Official site of "TradingEconomics.com". URL: http://en.tradingeconomics.com/russia/rating (reference date: April 5, 2017).

11. Russia will return its investment rating in 2017 [Electronic resource] / "News. Economics". - URL: http: //www.vestifinance.ru/articles/57610 (reference date: April 5, 2017). 